\title{
"Collapse" of Europe in the Light of Energy Dependence
}

\section{Marina Glamotchaka}

\begin{abstract}
The issue of the future of Europe is becoming increasingly important what with the depth of the economic crisis that started in 2008. In addition to a continuous growth in the number of the unemployed, the crisis particularly emphasizes the chronic level of energy dependence. The energy saving measures (energy efficiency), diversification of sources (stability of supply), and the creation of substitutes in renewable energy (energy transition), intertwine with administrative measures and form the response of European countries to the growing energy dependence. At the same time, although facing the threatening warming (or cooling) of the Earth, Europe, as a big advocate of reducing $\mathrm{CO}_{2}$ remains passively dependent on NATO (North Atlantic Treaty Organization) policy in the field of defense in the context of energy dependence. However, for the first time after many decades, Europe and America do not have the same energy, and consequently geo-strategic objective: The US has become energy independent while Europe is chronically energy dependent.
\end{abstract}

\section{Keywords}

Energy transition, energy security, energy dependence, climate change, defence

The dominance of the old continent ${ }^{1}$ during the nineteenth and early twentieth century, relies on the power of its industry, great naval powers, and colonial expansion. Europe liberates man from the shackles of ignorance (the philosophy of religion according to Calvin) and despotism (Montesquieu's political philosophy). Then, it developes individual hedonism as a reflection of the cult of labor and economic prosperity in the general social atmosphere of political democracy. Two world wars (1914-1918 and 1941-1945), fought on European soil, weaken the European impact while, the economic powers of the United States and Japan constantly expand since then. At the military level, the Cold War (1947-1991) and the Fall of Communism (1989) tie Europe military wise to the policy of the United States through NATO (North Atlantic Treaty Organization). At the economic level, the world monetary policy is linked to the dollar and Europe massively imports American high technology. The total number of citizens of the European Union (EU) is 500 million, but the European population shares in the world population is only 7.5\% (Lacroix 2010: 38). Economic growth is slowing down and barely reaches 2\%, and European countries are overburdened with debt...

During the 60s and the 70s, Western Europe does not dominate the world, but its economy is stable and its population never before had such a high standard of prosperity (cheap petrol allows the

aATOS Juris, France

\section{Correspondent Author:}

Marina Glamotchak, 90, Rue Victor Hugo, 9310 Bagnolet, France

E-mail: mglamotchak@gmail.com 
reconstruction of the industrial sector and a good product placement).

However, during the 90s, and despite certain dynamics (the European structures, common European market, unified monetary policy, the definition of the Schengen area, the integration of many Eastern Bloc countries into the EU, etc.), Europe is faced with even more growing dependency of its economy and concrete industries, and consequently its prosperity on imported energy. Europe does not have any direct access to fossil fuels and as the nuclear threat becomes real after the nuclear drama in Fukushima (2011), governments make decisions about the phasing out of nuclear power plants.

At the same time, the national economy and state protectionism (the regularization of national markets) are sanctioned in the context of economy liberization (the deregulation of national markets and abolition of state monopolies). The establishment of a unified world market (globalization) reduces the ability of nation states to encourage the development of their economy. The process of globalization deindustrializes Europe, and being less competitive it definitely loses control of its exports.

Sociologists and economists mainly indifferent in the mechanisms of the phenomenon of globalization, analyze its consequences (deindustrialization, migration flows, international tourism). The analyses do not indicate any concern regarding the fact that Europe loses its military, political, and now economic power in the course of a single generation. Capital and its enlargement instigate the process of transferring a huge part of the European savings and profits to countries where labor is inexpensive and profit is huge. At first, the effects are minor (layoffs, factory closures, privatization) and can be justified by technological advances of Europe, which takes for itself only "clean" industries in the new world division of the labor market. The fact is that " $50 \mathrm{~kg}$ of optical fiber can send more messages than one tonne of copper" (Kodjo 1988: 273).
Are the progressive weakening of Europe, expressed by the language of code and official economic reports made by Eurostat and the World Bank as well as its weight on the world stage, sufficient indicators of the "collapse" of Europe? Today's Europe, although weakened, belongs to the part of the world which directs its future toward the "foreseeable evolution" (technological upper hand, the use of asymmetric wars, etc.) and thus keeps its potential antagonistic forces at bay.

On the other hand, the thesis that there is a historical correlation between economic development and energy consumption/production does not take into account the following factors: The new available technologies, development of new energy sources and energy efficiency.

In the economic and geopolitical constellation in which the countries of rapid economic development need energy, there exists a growing influence of countries which possess raw materials and, therefore, have the ability to control the economy of countries import ingenergy. Consequently, Europe's energy dependency points to a different type of correlation: The economic development equals the level of energy availability.

\section{ENERGY SECURITY OF EUROPE}

The concept of energy security, created in response to the oil shock $(1973)^{2}$, ensures the coordination among industrialized countries in the event of disturbance in the energy field and provides a framework of cooperation $^{3}$ in the field of energy policy. Here the energy security is focused on finding solutions for the supply disorders caused by the producing countries.

The economic recession introduces the principle of rationalization of the supply of oil and petroleum products thus making a real progress in the understanding of energy security.

Energy security is not specifically defined or determined in an explicit way. At the state level, it is 
about "energy self-sufficiency" (possessing the energy park) and the need to import energy (energy dependence). At the global level, however, there is a general, dominant vision in the energy relations, the "energy dichotomous paradigm". Energy security is treated solely as an issue of the consumer countries-which is why the terms "energy security" and "security of energy supply" are considered identical.

Sustainability of economic growth in developed countries (Green Paper: A European Strategy for Sustainable, Competitive and Secure Energy 2006) is closely related to energy supply ${ }^{4}$, therefore it analyzes the conceptual categories of energy security relies on:

(1) Security components (geopolitics of risk, securitization of infrastructure, long-term stability of foreign investments in energy systems, stability of energy contracts, and prospection of potential risks);

(2) Measures taken to reduce energy dependence (saving energy expressed through energy efficiency, interconnection of space, increasing competition in the energy market, diversification of energy suppliers, improvement of energy infrastructure and energy stocking, increasing the risk of dependence for countries that have energy).

The authors put energy dependence in the foreground as an essential item in the definition of energy security. The import of energy still determines the EU, in spite of nuclear energy and renewable energy sources. Risk of additional energy dependence of the EU is based on:

(1) Brutal termination of energy supply (natural disaster or technical breach, act of terrorism and/or political decision);

(2) Risk of insufficient investments (new energy sources, stockpiling, transport infrastructure);

(3) Risk of having only one supplier (diversification of suppliers is needed);

(4) Dependence in the countries of transit;

(5) Climate change.

\section{EUROPEAN ENERGY NEEDS AND MEASURES TAKEN}

EU is the world's greatest importer of energy: More than half (54\%) of the energy consumed is imported (EUR 400 billion per year), despite the decline (6\%) of the total consumption in recent years. Between 2001 and 2013, the energy dependence ${ }^{5}$ of the EU increases from $47 \%$ to $53 \%$ (allenergy sources). In 2013, nuclear energy with $29 \%$ accounts for the largest portion of the energy consumption in the EU followed by renewable energy sources (24\%), solid fuels (20\%), gas (17\%), and oil (9\%). The EU imports $80 \%$ of its oil and $60 \%$ of gas. The import of energy still determines the EU, inspite of nuclear energy and renewable energy sources, especially the Russian gas that participates with 39\%, Norwegian with 33\%, and North African (Algeria and Libya) with 22\% to the total gas imports in the EU.

Denmark is the only country in the EU that is energy independent, followed by Romania (due to its production of oil, coal, nuclear, and hydroelectric power plants and small energy consumption). Estonia reduces its energy dependence from $32 \%$ to $17 \%$ between 2001 and 2012, due to its processing of oil shale, but with the increase in $\mathrm{CO}_{2}$ production (Clairet 2014).

"Europe's economic crisis, the maturity of its economy, its stagnant demographics and its efforts to reduce fossil fuel use are lowering expectations of future energy demand. Despite this, Europe's import dependency on fossil fuels is expected to rise" (Dreyer and Stang 2013: 1). Demand for energy is growing, especially gas, in the context of "clean energy" and the reduction of $\mathrm{CO}_{2}$, and by 2030, it is expected to increase by $27 \%$.

The figure below shows the consumption of Russian gas (136 billion $\mathrm{m}^{3}$ per year) in the context of overall spending of EU countries. At first glance, it is obvious that the EU countries that once belonged to the Soviet Union (Slovakia, the Baltic countries, 


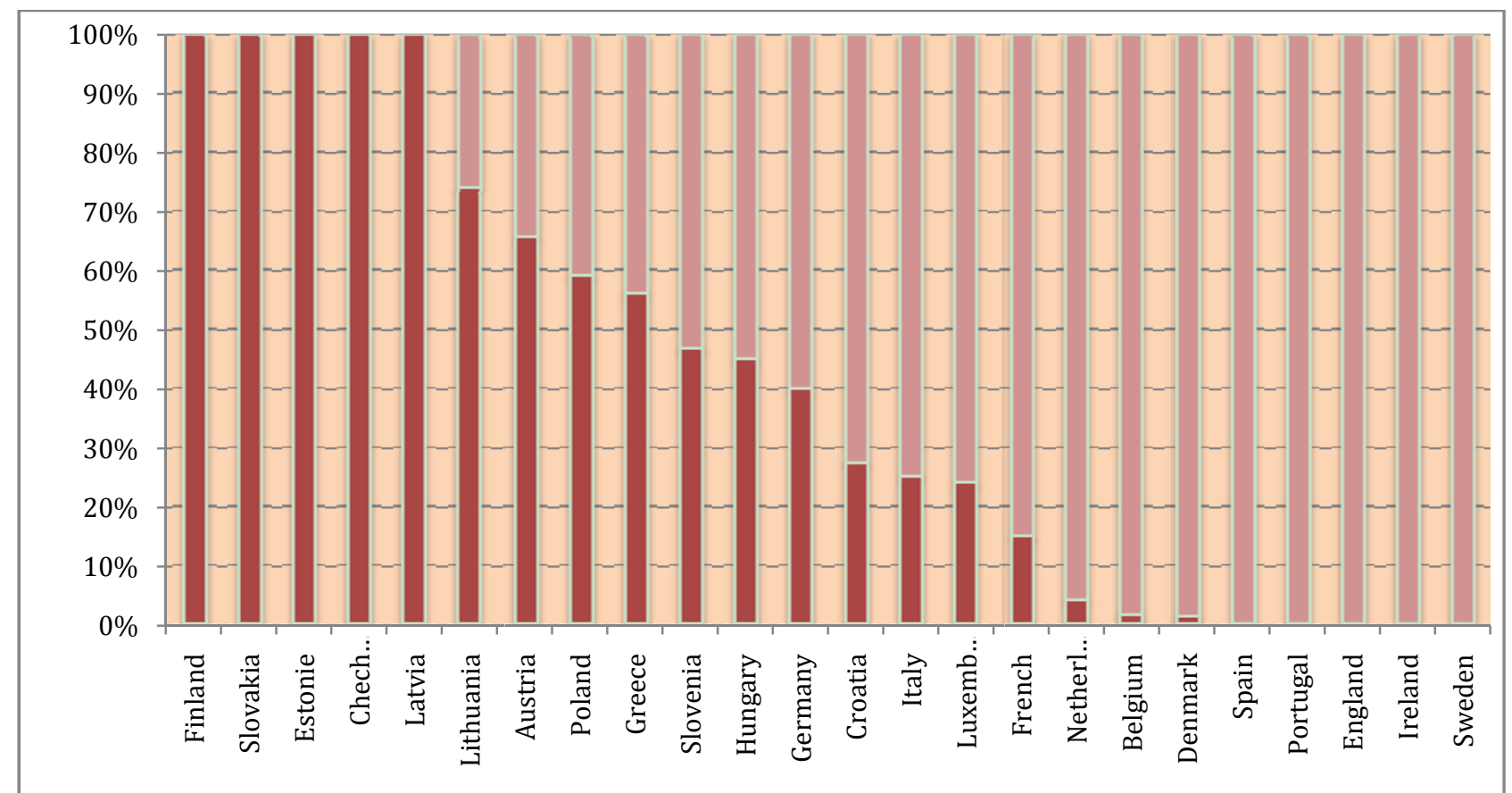

Figure 1. Consumption of Russian Gas Within the Total Consumption of the EU Member States. Source: the figure created by the data of the International Energy Agency, Organization for Economic Co-operation and Development (OECD), and Eurostat.

Poland, Hungary, Czech Republic) have an extremely high level (from $47 \%$ to $100 \%$ ) of consumption of Russian gas in the general consumption. The reason for such a high dependence is that their infrastructure dates from the Soviet period and that, therefore, these countries are oriented to Russian gas. Within the Energy Community as a general EU policy for energy, the EU policy tends to make a system of connections by which gas will circulate in both directions and the countries will not be dependent only on one source, namely Russian gas.

Successive crises (2006, 2009, 2014, and 2015) between Ukraine (the territory over which $80 \%$ of Russian gas is exported to Europe before building the Nord Stream) and Russia (large exporter of gas) contribute to the European Commission to adopt a new strategy in order to ensure energy supply and reduce the EU's dependence on imported energy.

In addition to energy savings, the new strategy of struggle for energy security (2014) is based on:

(1) Diversification of sources of supply based on the expansion of gas infrastructure with Norway, on the Southern Corridor (gas from Azerbaijan) and Mediterranean (gas from Algeria) and increased use of NLG (natural liquid gas);

(2) Modernization of energy infrastructure;

(3) Completion of the internal energy market with the development of infrastructure links (raccordement);

(4) Increasing its own production of energy (increase in the share of electricity from $10 \%$ to $15 \%$, the development of renewable energy sources, and the exploitation of hydrocarbons and pure coal);

(5) Better coordination of national energy policies and unified appearance in foreign energy policy.

In this regard, the European Commission announces the creation of the Energy Union (25/02/215), as a major energy project of $28 \mathrm{EU}$ 
member states. The focus of the Energy Union is determined by five complementary dimensions: energy security, solidarity, and trust; the internal energy market; energy efficiency, which contributes to the moderate consumption of energy; reducing $\mathrm{CO}_{2}$ emissions in the economy, as well as research, innovation, and competitiveness. The novelty is also in the legal measures which are intended to achieve compliance with the rules of the internal market and the criteria for security of supply. In particular, so far checking the conformity of bilateral agreements is done after a EU member state and a non-EU country come to an agreement. In the future, the European Commission should be informed about the process of negotiation of intergovernmental agreements from an early stage so as to ensure their compliance with the rules of the internal market and the criteria for security of supply. This would ensure the unity of the EU in negotiations with third countries. It is interesting that the Energy Union, as a highly centralized project, comes at a time when the European project is not generally popular, which requires additional political intervention in order to be achieved. In addition, the European Commission does not adequately take into consideration the fact that in most member states, energy companies are state-owned what, in turn, allows the states to have control over energy supply and, to some extent, prices of energy and social policy (what with growing percentage of inability to pay energy use). It remains an open question how and in what time frame will the EU member states, for which the energy policy is a vital national policy leverage, transfer their sovereign "right to energy" at the centralized system conceived in the framework of the Energy Union.

Let us return to the beginning: The position of a significant consumer of Russian gas gives the EU the right to regulate the Russian energy influence on its territory. Motivated by fear of an excessive dependence on Russia and relying in part on the "energy transition" and diversification of sources,
Brussels strategies rely on the power of norms and adopt, among other norms the Third Energy Package $^{6}$... But if diversifying the sources is the goal of European security, which essentially means access to non-Russian sources of gas, then its costly and long-term implementation must be amended by other concrete measures (reduction of energy consumption, strengthening of alternative energy sources, research funding, etc.). After all, the Russian decision that Gazprom suspends gas supplies to Europe through unstable Ukraine territory starting from 2019 puts Europe before a new energy challenge: gas...

\section{FROM ENERGY DEPENDENCE TO ENERGY UNCERTAINTY OF EUROPE}

The argument that the global economic activity is dependent on geopolitics related to energy (gas, petrol) is affirmed with the production of gas and petroleum from oil shale (in the US) and the production of energy from renewable sources. This new "energy mix" produced domestically threatens to change the hitherto "geostrategic code" in the energy market.

However, a new "war" started by Saudi Arabia", and waged with reducing the price of oil barrels is initially aimed at regulating oil market (too much supply in relation to demand created by the production of oil from oil shale primarily by the United States and Canada, but also disabling Iran to enter the market). Destabilization of Russia using energy as weapon [more than 70\% of its GDP (gross domestic product)] and Venezuela facing an economic collapse are the direct consequences of oil price falling. But it turns out that this is just the tip of the iceberg. A real devalorization of investments in renewable energy and, in particular, the emergence of a market atmosphere in which, American investment in oil and gas production proves unprofitable ensue (Node-Langlois 2014).

On the other hand, the fall in price of barrel oil could lead to economic growth in Europe, but the EU position regarding the reduction of greenhouse gases 
could be at stake twofold: by the devalorization of investments in renewable energy and the reduction of the share of gas in total energy mix. The process of distancing Europe from Russian gas imports in order to prevent energy dependence on Russia (diversification of sources, opening the American-European Southern Gas Corridor, which simultaneously allows the strengthening of the energy impact of Turkey, preventing the Russian gas pipeline Nord Stream to operate at full capacity ${ }^{8}$, and finally blocking the South Stream gas pipeline megaproject) leads to energy in security in Europe (Glamotchak 2013: 49).

Sanctions imposed on Russia for the Ukrainian crisis and the annexation of the Crimea (March 2014) take the EU energy uncertainty to yet a higher level.

With the introduction of sanctions and by creating a "rift" (Gomart 2015) with Russia, the EU makes moves that are in favor of its own damage. Namely, on April 17, 2014, the European Parliament passed a resolution which calls for the construction of the South Stream ${ }^{9}$ to be suspended and that the EU's dependence on Russian oil and gas be reduced by "diversification of sources of energy supplies". In this sense, at the request of the European Commission and US senators, Bulgaria suspends the work on the realization of the South Stream. Bulgaria is otherwise the most important land route of the South Stream, which enters its territory from the Black Sea and then divides into the leg that goes toward the Western Balkans and the other leg that goes to Greece and under the Adriatic Sea to enter Italy. The EU pressure makes Russia withdraw (December 2014) from this mega project (capacity $63 \mathrm{~m}^{3}$ ) and this, among other things, brings great damage to European energy companies that take part in the construction of the gas pipeline (Italian ENI 20\%, German Vintershel 15\%, and French EDF 15\%). However, the abandonment of the South Stream makes the most damage to the countries of Southeast Europe to which, in essence, the gas from this pipeline is intended (Glamotchak 2013). Russia's decision to halt the Ukrainian transit ${ }^{10}$ of Russian gas starting from 2019 (which provides $100 \%$ of gas that Serbia, Moldavia, Slovakia and Slovenia need, $50 \%$ of gas required by Austria, Greece, Czech Republic, and Croatia and $40 \%$ by Italy) further threatens the energy situation in the countries of South-Eastern Europe.

The isolation of Russia due to its support being given to pro-Russian forces in the Ukrainian civil war, the sanctions imposed upon Russia by the US and EU, casting Russia out of the G8 (Group of Eight) of the most powerful economies in the world and, in the end, the suspension of the construction of the South Stream, all this makes Russia take three essential steps that will further jeopardize EU energy security:

(1) To sign an agreement with Turkey on the construction of the "Turkish Stream" gas pipeline (which could be finished by 2016, and would replace the Nabucco, the unrealized American-European project, by a good deal of its route). With the decision on the termination of gas supplies via Ukraine, starting from 2019, Russia puts Europe in a situation to build a new pipeline from the Turkish border through the Balkans in only a few years. Namely, after the construction of the Nord Stream and having planned the South Stream Gazprom ${ }^{11}$ reduces transit in this direction at 62 billion $\mathrm{m}^{3}$ in 2014 (137 billion $\mathrm{m}^{3}$ in 2004) due to the uncertainty of the Ukrainian route. Now this amount of Russian gas (62 billion $\mathrm{m}^{3}$ ) is offered Europe, but by way of the Turkish Stream. In principle, the decision to abandon the South Stream and the construction of the Turkish Stream is the end of Gazprom's model in accordance to which the company focuses on direct gas supplies to final consumers in the European market. The point of Russian supplies to European consumers is now at the Turkish-Greek border. Consequently, Russia avoids European regulations of the Third Energy Package and introduces Turkey as a key link European energy (in) dependence;

(2) To reduce the delivery to the EU and focus on diversifying export routes and participate in the 
markets of South America and India with LNG (liquefied natural gas)...

(3) To turn to BRICS (Brazil, Russia, India, China and South Africa) ${ }^{12}$ countries, especially China and sign 51 contracts with it (May, 2014). Energy has a special place in these contracts (worth $\$ 400$ billion) as well as the construction of the Power of Siberia (investment of 55 billion dollars by the Russians and \$25 billion by the Chinese), a 4,000 kilometers long gas pipeline with an initial capacity of $38 \mathrm{~m}^{3}$ to reach the capacity of $60 \mathrm{~m}^{3}$ (as the South Stream is supposed to have). The Union of Russia with China and the countries of rapid economic development, is a new reality, which the European Energy Policy is facing.

The EU-USA Summit (March, 2014) ended with the promise of President Obama that the Europeans get American gas, and without the decision of the congress, too. The fossil fuels in the US are considered as strategic national product and the export license is necessary, especially for gas. This rule has two exceptions: In case the United States has signed a free trade agreement with a country, and when the president permits certain exports but always in the name of national security.

Given that energy security is one of the factors of general security, preparations for NLG-import from the United States will be on the agenda in the negotiations on the Transatlantic Free Trade Area (TAFTA) between the EU and the United States. "Economic NATO" as Hillary Clinton refers to this transatlantic agreement (Regnier 2013), will circumvent the previous administrative restrictions on natural gas exports from the US to the EU.

But, this ambitious and expensive project of substituting Russian gas to American LNG will reduce Europe's dependence on Russian gas neither in the short term, nor in the long run (Bordoff and Houser 2014: 32). Politicized discourse on both sides of the Atlantic puts reality, perspective and the possible consequences of NLG exportation from the USA in the shadow. Firstly, the European network of terminals for NLG processing is not sufficient enough to put through 160 billion $\mathrm{m}^{3}$, the amount Russia delivers to the EU annually. Even if such an amount of available NLG existed and those imports were possible, the entire territory of the EU is not covered by the network of NLG terminals, thus parts of Central and Eastern Europe would remain without gas in the event of interruption of Russian gas supplies...

Repositioning of the main actors (USA, Russia) on the international energy scene will not reduce Europe's energy dependence.

\section{GLOBAL WARMING AND CLIMATE CHANGE}

Regardless of whether the Earth is getting warmer or cooler (Dixo 2013), the term climate change means rapid and, in the near future, catastrophic change of climate caused by human activities, primarily the exploitation of fossil remains (petrol, gas, coal) which emit toxic gases $\left(\mathrm{CO}_{2}\right)$ and pollute the atmosphere.

The EU as a global leader in the fight against climate change, has made the decision (October 2014) to reduce $\mathrm{CO}_{2}$ emissions by $40 \%$ by the year 2030 and to increase the participation of renewable energy sources to $27 \%$ (instead of $20 \%$ ). At the conference in Lima (December 2014), a part of the negotiating text is agreed on the basis of which a new global agreement (COP 21), will be signed at the conference in Paris (December 2015), which is to replace the current 2020 Kyoto Protocol.

A groundbreaking agreement between the two largest polluters, China ${ }^{13}$ and the United States to reduce emissions of $\mathrm{CO}_{2}$ instills a renewed optimism that the negotiations at international level will finally find a way to stabilize global warmingatan average temperature increase of $2^{\circ} \mathrm{C}$.

“The ecology capitalism” or natural capitalism (Hawken 2008), should also enable economic development and reduce $\mathrm{CO}_{2}$ emissions... 


\section{ENERGY TRANSITION}

The concept of energy transition (Green Deal) initially ment the cessation of fossil fuel exploitation (large emitters of carbon dioxide) and reduction of the greenhouse effect. But the frequent occurance of this idea in the media leads to a change in its meaning: Nuclear reactor shut down (such reactors do not produce $\mathrm{CO}_{2}$ ) and the transition to renewable energy sources (which in their own way again emit $\mathrm{CO}_{2}$ ). The new energy and environmental "Holy Grail" 2013: 43) becomes a kind of secular religion. Namely, the energy transition should enable humanity to "live in paradise" (from the wind, the sun ${ }^{15}$, or the sea) and it has a revolutionary character (as steam engine or electricity did once). In this sense, the convergence between the numerical and energy world (Rifkin 2012), in which no additional energy is produced but there is only numerical rationalization of energy, will it save Europe and the world?

De facto, the risk associated with climate change gives importance to renewable energy sources. The fundamental principle of energy transition relies on the development of solar and wind energy because they are the most competitive in comparison to other types of renewable energy sources (biomass, hydraulic, geothermal energy, etc.).

No matter the fact that the cost of production from these so-called "fatal sources"16 is high (Safa 2013: 81), that it is necessary to build a new network of high-voltage transmission lines as well as new stock piles with numerous technological limitations, the EU clearly defines its energy and climate objectives (Sapy 2013: 10) called "3 times 20" (20\% increase in energy efficiency, 20\% reduction in harmful emissions, and 20\% larger use of alternative energy sources) by 2020 . This administrative decision does not, at least for a decade, change reality: Energy from renewable sources is too expensive and subsidized by the state, and still does not bring the miraculous solution that substitutes the use of fossil fuels. At the same time, this issue is related to the issue of ownership and capital (the aggregate value of the coal, oil and gas companies spikes over 5,000 billion dollars (White Paper 2014: 1). The conclusion that renewable energy sources can be only a supplement to the choice between nuclear power and/or gas, the two sources that do not emit $\mathrm{CO}_{2}$, again raises the question of energy dependence...

In addition, the model of "centralization of power" (the centralized model of production and distribution of energy), is replaced by the model of "diversification" from the 90s, which transforms the attitude toward energy (activities of producing, transporting, distributing, and stocking energy are divided).

The basic paradigm of the EU energy policy is Europe's energy security and reduced $\mathrm{CO}_{2}$ in the context of climate change. However, its results are controversial for now.

The paradox of energy derived from renewable sources is the necessity of their balancing in the frequent cases of reduced production of energy from wind and sun. Despite the growth of renewable energy sources in Europe, coal power plants play a vital role in ensuring energy security on the European continent! In particular, it is important to secure substantial funding for the stabilization of power systems, especially the one in Germany, which has the highest percentage of "clean energy". The companies which signed for the accession to this expensive system of market balancing, and may be paid even 400 times above the price of electricity on the wholesale market for this emergency intervention, principally use the coal power plants...

Subsidizing electricity production from renewable energy sources in an unbalanced fashion leads to the neglect of production from conventional power plants. In addition to the increase in electricity prices, a direct consequence of such a policy is an important dissipation of stable electricity sources and destabilization of electrical energy systems (due to a 
lot of unstable sources, particularly wind and solar power plants and their balancing).

\section{DEFENCE AND CLIMATE CHANGE}

Climate disasters (tsunami, floods) are one of the aspects of global warming of the planet. The changed geography of Earth leads to a new geopolitics, new challenges and planetary threats-a sector which presumes direct military and climate change linking.

Climate change is an additional challenge to the concept of defense, not only in geopolitical or doctrinal orientation but also in the field of military industry and operability of actions in crisis management. The defense system adapts in the new context of risk that is directly caused by climate change. The concept of "green defense", based on preventive approach, redefines the classic military doctrine.

Studies on the relationship between defense and climatic conditions are in the realm of change and environment security (environnement) (Maertens 2012), and they examine the relationship of society depending on natural conditions. Scientific research on the relatively rapid climate change, particularly in certain regions (sea level rise, lower salinity of the sea, melting glaciers, the invasion of insects and with them the development of many diseases, lower hydration, etc.) as well as political actions that follow (policy planning and development), raise awareness of the consequences that climate change may have on the population and the general security (national or international). Identified risk of climate change (Quenault 2009: 183), expressed as “climate security”, is oriented toward the strategy of crisis management and is beyond the scope of studies on the environment.

"Hydro-diplomacy" (with the possible lack of water), is a new paradigm that follows right behind the energy-diplomacy. At the same time, the rapid militarization of the Arctic, the geopolitics of which changes due to rapid dissolve, is an enormous energy potential as well as a supply of rare minerals that the United States, Russia, China, Canada, Denmark, and the EU are interested in.

Climate change is an additional challenge to the concept of defense in:

(1) Geopolitical and/or doctrinal orientation;

(2) The field of military industry [large emitter of GHG (greenhouse gas)]. Despite the general appeal for reduction of gas emissions, the defense sector remains a privileged one because the primary objective of the military operation is to obtain optimal results with the minimal number of direct victims. Climate change is not significantly involved in weapons programs. Defense industry cannot get rid of considerable potential of high performance military armored transportation vehicles (ATV) intended for areas with high temperatures although their release of chlorofluorocarbon (CFC) (chemical compounds containing atoms of chlorine, fluorine, bromine and carbon) surpasses $\mathrm{CO}_{2}$ emissions by far;

(3) Operability of action (gestion de crise-crisis management);

(4) Geo-engineering domain: experimenting to military and civilian ends.

The standpoint that climate change is largely generated by human activity and mismanagement is expressed with the so-called anthropogenic factor (anthropogenic factors). The development of geo-engineering (or climate engineering) is initiated by "fixing" the situation, i.e., climate deregulation. Geo-engineering presumes large experimental interventions in the earth's climate composition, the goal of which is climate change through technology. Specifically, it is about the search for a method to reduce $\mathrm{CO}_{2}$ (as the cause of climate change and greenhouse effect) and control solar radiation. The first method is based on the experiment of introducing large amounts of iron (ferrous sulfate) in the oceans (the process of "fertilization" in order to accelerate the growth of certain algae capable of great absorption of 
gases) or capturing $\mathrm{CO}_{2}$ directly from the air. The second method is based on the increasing of sun ray reflection directly from the Earth back into space (spraying dust particles over Arctic, releasing sulphate particles-chematrails - in the atmosphere or cloud production to maximize the reflective surface so as to create a kind of shield that would rebuff a part of the solar radiation) which would, in turn, lower the temperature of the earth. The possibility of unilateral action and wild experimenting should be added to the risk of experiment conducting and the lack of knowledge about the impact of these methods on the atmosphere, change of $\mathrm{CO}_{2}$ cycle, and the overall ecological and climate system of the planet.

The use of geo-engineering is also possible to the military ends ${ }^{17}$ by which the share of non-military means of combat is greatly increased and is the range of military action. Their main goal is not to defeat the enemy momentarily but to accomplish a destabilization of the countries and region by invoking natural disasters (the possibility of an impact on climate change). Geostrategic repositioning in the period of the fall of communism, innovation and high technological progress as well as the experience gained during the Gulf War (1991) or the bombing of Serbia (1999) bring a host of new opportunities to the military in the perspective of global conflict.

Bearing in mind the high level of the destructiveness of climate management technology war application, the ENMOD Convention (1977), the first international agreement fully dedicated to the environmental aspects of armed conflict conduct, prohibits any deliberate abuse of natural processes in offensive purposes. Since 1998, the independent Group for Research and Information on Peace and Security (GRIP), based in Brussels has an observation center called the Army and the Environment, which aims to study the impact of military activities on the political, economic, legal, scientific, and ethical level. The GRIP believes that projects such as the High Frequency Active Auroral Research Program
(HAARP) should be investigated by an independent international body, primarily because of their overall impact on the global environment (Mampaey 1998).

Paradoxically, the EU, as the leader of the fight against gas emissions and greenhouse effect, still has no common defense policy in the context of climate change, but relies on "a new factor inthe crisis development” (Lagneau 2013). More specifically, instead of a military approach, the member states of the EU generate Civil Protection, which would anticipate natural disasters and have the capacity to "rapid reaction force" (Fabrégat 2010: 3). National defense remains the category of each respective state. The EU Program (FP-Framework Program) on climate change and its impact on the security of Europe has been developing since 2007. The aim of the program is to identify areas that are most likely to be affected by climate change and the risk that is most likely to occur, either single (floods, the Sun, cyclones, drought, etc.) or in a cumulative form. In other words, the defense system should adapt and be operational in the new context of risk that is directly caused by climate change. Therefore, each state links defense and climate change in its own way (environmental safety, climatic safety, climatic disasters, etc.). One of the reasons for such state of affairs is certainly the lack of European security identity and its own strategic concept which, for now, is associated with the security policy of the United States and NATO.

In the US, however, the issue of climate change is not just a matter of environment. In 2003, it becomes a strategic challenge (Alex, Coldefy, and Kempf 2014: 13-19). The risk of sea level rising or warming of the Arctica, may lead to a lack of essential conditions for survival (lack of water and food), health problems (diseases, epidemics), but also to catastrophic social change (mortality of population rate, large-scale migration) with which, in turn, violence and risk of new conflicts are connected. The United States leads the world in the research of emerging strategic threats. According to the publication Quadriennal Defense 
Review Report 2014 (QDR), climate change is an essential preoccupation of US defense doctrine (Valentin 2013). In addition to the hazard analysis, the report raises the question of operational capabilities and support for military action to the purpose of civil protection (QDR 2014).

\section{CONCLUSIONS}

The ideas of "catastrophism" and fall results from the inability of present-day Europe to reverse the course of its social and economic evolution. Certainly, one reason for such state of affairs is that despite relatively well-developed technological capabilities in the field of energy, it is not easily to get out of three interdependent economic circles: production -consumption, technological progress-capital growth, and the prevalent production of energy from fossil fuels- $-\mathrm{CO}_{2}$ emissions.

But within the concept of energy independence, the EU cannot afford to reduce the number of its current options of energy sources (nuclear, coal, and gas). Half of the nuclear capacity in the EU, which is supposed to be removed in the next 10 years, essentially has to extend the service life. Energy transition, relying on renewable energy sources as a substitute, is a long process that depends on technological development and economic viability of renewable energy sources increasing in the energy systems and energy market in Europe. The diversification of sources of energy supply, by itself, does not necessarily guarantee energy security. If the aim of diversification is to access non-Russian sources of gas, then the European orientation on accessing alternative sources of natural gas supply is a risky strategy in which Europe moves from the state of stable energy dependence (on Russian gas) to the state of energy uncertainty.

Unlike previous civilizations, which also be fell the situation of lack of resources, "energy transition" is a term of (permanent) innovation. However, innovationcan be discussed only when technology is applied to a specific economic system with values and actors that can set in motion a new wheel of history (Provoost 2013: 8).

Europe is not on "civilizational decadence" road, but like the rest of the world, it is faced with the possibility of (self) destruction of nature caused by man. "Return to nature", to quote Edgar Morin, a French sociologist is a possibility to establish a relationship between man and economy in a different way in "political civilization” (Morin 2007). De facto, energy transition is not just a matter of engineers, or the issue of funding, but the essential matter of survival of a civilization in which the paths of energy and climate meet.

\section{Notes}

1. The author refers only to the Western Europe (European space which mainly comprises the European Union) and not to the Western civilization (which, in addition to the US and Europe, includes Japan because of its commitment to Western values, i.e., democracy and the free market).

2. Members states of the Organization of the Petroleum Exporting Countries (OPEC), use oil as a political weapon during the Arab-Israeli war in October 1973 and in the sense of energy consumption, this definitely divides the world to consumer countries and producer countries. According to this division, the actors maintain relationships of dependence and their interests express in antagonistic categories.

3. The International Energy Agency, based in Paris, was founded in 1974.

4. On the variety of indicators to determine the energy security see Scheepers, M. et al. (2007).

5. The rate of dependence on imported energy is defined as net imports divided by gross consumption. From a country that practically exports energy (-9\% in 2001), England becomes a major importer of energy (42\% dependence on imports in 2012).

6. Internal energy market in the EU is regulated by the "legislative package". The third package, which intervenes in the gas and electricity field to enable competitiveness requires that the transport infrastructure management and the production management are separated. Many authors believe that these measures are taken against the monopoly of Russian Gazprom and its two mega gas projects (Nord 
and South Stream).

7. Despite a slight increase in the crude oil price per barrel, and speculations that after the death of King Abdallah (January 2015) and the enthronement of King Samlan, the country would change its energy policy that did not happen. Ali Al-Naimi, the mighty Minister for Petroleum and Mineral Resources, continues with the same policy. By decreasing the price per barrel, Saudi Arabia protects its share in the energy market. Internally, a fall in the price per barrel of oil in the country with a galloping demography may in due course threaten social peace despite the fact that Saudi Arabia has significant financial reserves. On the other hand, numerous destabilizing processes are in progress in its surroundings.

8. The European Commission again postpones the decision (November 2014) on permitting Russia to expand the use of the Opal pipeline capacity although the supply of Russian gas to Central Europe would improve with this permission. The Opal, which is linked to Gazprom's Nord Stream gas pipeline, enables the connection of this gas pipeline with the Czech Republic and Central Europe. Officially, Gazprom's use of the pipeline is limited because of EU law on preventing any supplier to use the infrastructure predominantly, although in this case no one else uses the spare transportation capacity of the Opal! Nord Stream's capacity is 55 billion $\mathrm{m}^{3}$ of gas per year, but Gazprom annually transports only one half of that amount.

9. In order to circumvent Ukraine, and more than $80 \%$ of Russian gas to Europe was transported through the territory of this country, Russia develops two projects: the Nord Stream (finished in 2011, passing under the Baltic Sea and directly entering Germany), and the South Stream.

10. Since the release of the Nord Stream Russian gas pipeline (2011), only about $15 \%$ of gas imports to Europe pass through the territory of Ukraine.

11. Gazprom is the largest producer of natural gas in the world and the largest Russian national company.

12. The BRICS (Brazil, Russia, India, China and South Africa) was founded in 2008. It is the economic term for the rapid development countries. The cooperation between Russia and China is strengthened by the Shanghai Agreement (2001). In addition to regional cooperation, this agreement tends to prioritize the formation of a new financial system that would weaken the dollar dominance in all spheres of world trade.

13. "Every week, a new coal-fired electric plant is linked to the Chinese network. China was producing electricity as much as France 25 years ago. Today, it produces eight times more” (Safa 2013: 50).

14. The belief that the vessel from which Jesus drank, the Holy Grail, has magical powers.
15. Solar energy is 20 times more expensive than kwh of energy produced in a nuclear reactor.

16. These are the energy source that cannot be controlled and where energy should be taken at a given time.

17. The concept of HAARP (High Frequency Active Auroral Program), the American scientific project, or the Soviet Jet Stream and their numerous applications (Environmental Warfare for the purpose of Future Warfare: influencing the behavior of people, scanning the interior of the Earth in search of hidden bases, changing meteorological conditions, causing earthquakes, etc.) begin to develop ever since the $60 \mathrm{~s}$. One of the principles is exploring the ionosphere and electromagnetic waves (Valentin 2013).

\section{References}

Alex, B., A. Coldefy, and H. Kempf. 2014. Conséquences du dérèglement climatique pour le ministère de la Défense (Consequences of Climate Deregulation for the Ministry of Defence). Paris: IRIS.

Bordoff, J. and T. Houser. 2014. American Gas to the Rescue? New York: Columbia/SIPA. Retrieved (http://rhg.com/wpcontent/uploads/2014/09/American-Gas-to-the-Rescue.pdf).

Clairet, S. 2014. Panorama des dépendances énergétiques européennes (Panorama of European Energetic Dependence). Retrieved (http://geosophie.eu/2014/06/09/ panorama-des-dependances-energetiques-europeennes/).

Dixo, H. 2013. Global Warming? No, Actually We're Cooling, Claim Scientists. Retrieved (http://tinyurl.com/pyomunr).

Dreyer, I. and G. Stang. 2013. What Energy Security for the EU. Paris: EU Institute for Security Studies. Retrieved (http://www.iss.europa.eu/uploads/media/Brief_39_Energy _security.pdf).

Fabrégat, S. 2010. Catastrophes naturelles et humaines: une force d'intervention d'urgence européenne dès 2014 (Natural and Human Disasters: A European Emergency Task Force Since 2014). Retrieved (http://www.actuenvironnement.com/ae/news/inondations-coulees-boue-108 27.php4\#xtor=EPR-1).

Freund, E. and P. Lucchese2012. L'Hydrogène, carburant de l'après-pétrole (Hydrogen, Post/After Oil Fuel). Paris: Technip.

Glamotchak, M. 2013. L'enjeu énergétique dans les Balkans: Stratégie russe et sécurité européenne (Energetic Stake in the Balkans, Russian Strategy and European Safety). Paris: Technip.

Gomart, T. 2015. Les conséquences du schisme russo-occidental (Consequences of the Russian-Occidental Schism). Paris: Revue de deux mondes, février. Retrieved (http://www.ifri.org/sites/default/files/atoms/files/thg_2015 -01-291532revue_des_deux_mondes.pdf). 
Green Paper: A European Strategy for Sustainable, Competitive and Secure Energy. 2006. Retrieved (http://www.clingendael.org/publications/2006/20060600_c iep_misc_dejong-maters-et-al.pdf).

Hawken, P. 2008. Natural Capitalism. Paris: Scali. Retrieved (http://www.lefigaro.fr/conjoncture/2014/12/23/20002-201 41223ARTFIG00165-petrole-l-arabie-saoudite-declare-la-g uerre-ouverte-aux-americains.php).

Kodjo, E. 1988. L'Occident, du déclin au défi (Occident, From the Decline to the Challenge). Paris: Stock.

Lacroix, A. 2010. "Le déclin de l'empire européenne" (The Decline of the European Empire). Philosophie 42:35-41.

Lagneau, L. 2013. "La Loi de programmation militaire prend en compte les risques liés au 'changement climatique”" (The Law of Military Programmation Takes in Charge the Risks Linked to "Climate Change"). Zone Militaire, December 11. Retrieved (http://www.opex360.com/ 2013/12/11/la-loi-de-programmation-militaire-prend-en-compte -les-risques-lies-au-changement-climatique/).

Maertens, L. 2012. "La sécurité environnementale et le processus de sécurisation: définitions et enjeux théoriques" (Environmental Safety and Security Process: Definitions and Theoretical Issues). Fiches de l'Irsem 17:11.

Mampaey, L. 1998. Le programme HAARP: Science ou désastre (Program HAARP: Science or Disaster)? Bruxelles: GRIP, Les rapports du GRIP.

Military Green 2013. 2013. Report From Workshop Series, June 6-7 and June 13, 2013, Agence européenne de defense (European Agency of Defense) (AED). Retrieved (http://www.eda.europa.eu/docs/default-source/documents/ military-green-2013-report.pdf).

Morin, E. 2007. De L'An I de l'ère écologique: la Terre dépend de l'homme qui dépend de la Terre (From the Year I of the Ecological Era: The Earth Depends on the Man Who Depends on the Earth). Paris: Tallandier.

Nodé-Langlois, F. 2014. "Pétrole: l’Arabie saoudite déclare la guerre ouverte aux Américains” (Oil, Saudi Arabia Declares an Open War to the Americans). Le Figaro, December 23. Retrieved (http://www.lefigaro.fr/ conjoncture/2014/12/23/20002-20141223ARTFIG00165-pe trole-l-arabie-saoudite-declare-la-guerre-ouverte-aux-ameri cains.php).
Provoost, R. 2013. Énergie 3.0 (Energy 3.0). Paris: Cherche midi.

Quenault, B. 2009. “Climate Change and Security Risks.” Pp. 181-194 in Une économie politique de la sécurité (A Security Policy Economy), edited by C. Serfati. Paris: Hartaala.

Régnier, Ph. 2013. Marché UE-USA: une revanche, un pari et des dangers (EU-US Market: A Hand, a Bet and Dangers). Paris: Le Soir: 14 février.

Rifkin, J. 2005. Le rêve européen ou Comment l'Europe se substitue peu à peu à l'Amérique dans notre imaginaire (The European Dream: How Europe's Vision of the Future Is Quietly Eclipsing the American Dream). Paris: Fayard.

- 2012. La troisième révolution industrielle: comment le pouvoir latéral va transformer l'énergie, l'économie et le monde (The Third Industrial Revolution: How Lateral Power Is Transforming Energy, the Economy, and the World). Paris: LLL.

Safa, H. 2013. Quelle transition énergétique (What Energy Transition)? Paris: EDP Sciences.

Sapy, G. 2013. La transition énergétique (The Energy Transition). Paris: l'Harmattan.

Scheepers, M. Seebregts, A. de Jong, J. Jacques, and H. Maters. 2007. EU Standards for Energy Security of Supply. Clingendael: Netherlands Institute of International Relations. Retrieved (http://www.clingendael.org/ publications/2006/20060600_ciep_misc_dejong-maters-et-a l.pdf).

Valentin, J.-M. 2013. Guerre et Nature, L'Amérique se prépare à la guerre du climat (War and Nature, America Is Preparing for Climate War). Paris: Editions Prisma.

White Paper. 2014. Bloomberg New Energy Finance, August 25. Retrieved (http://about.bnef.com/content/uploads/sites/ 4/2014/08/BNEF_DOC_2014-08-25-Fossil-Fuel-Divestme nt.pdf).

\section{Bio}

Marina Glamotchak, Ph.D. in sociology, senior research fellow in several institutes and research centres in France, consultant, ATOS Juris (France); research fields: energy, sociology of defence, and geoeconomy. 